\title{
EFFECTIVENESS OF SHORT MESSAGE SERVICE REMINDERS AND LEAFLETS IN COMPLYING WITH IRON SUPPLEMENTATION IN PREGNANT WOMEN IN DEPOK CITY, INDONESIA
}

\author{
DINA ANITASARI, RETNOSARI ANDRAJATI* \\ Department of Pharmacy, Faculty of Pharmacy, Universitas Indonesia, Depok, Indonesia. Email: retnosaria@gmail.com
}

Received: 21 April 2017, Revised and Accepted: 13 July 2017

ABSTRACT

Objective: Lack of knowledge about iron supplementation among pregnant women contributes to poor compliance with the therapy. The use of media such as leaflets and short message service (SMS) reminders can be used to improve compliance. This study assessed the effectiveness of SMS reminders and leaflets in complying with iron supplementation in pregnant women.

Methods: This quasi-experimental study used two intervention groups with a pre-test and post-test group design. This study was conducted from March to May 2016 in two public health centers in Depok City, Indonesia. A total of 38 respondents in Sukmajaya were given leaflets, and 36 respondents in Pancoran Mas received SMS reminders. Patients' compliance was measured using the MMAS-8 questionnaire, and their hemoglobin levels were measured with HemoCue ${ }^{\circledR}$.

Results: A total of 19 respondents in the leaflet group experienced an increase in their hemoglobin levels (with an average of $0.6 \mathrm{~g} / \mathrm{dl}$ ). A total of 17 respondents in the SMS reminders group experienced an increase in hemoglobin levels (with an average of $1.1 \mathrm{~g} / \mathrm{dl}$ ).

Conclusions: There was no difference between leaflets and SMS reminders in terms of improving patients' compliance with iron supplement consumption or with increased hemoglobin levels ( $\mathrm{p}=0.576$ and $\mathrm{p}=0.929$, respectively).

Keywords: Compliance, Iron supplement, Leaflet, MMAS-8, Pregnant women, Short message service reminder.

(C) 2017 The Authors. Published by Innovare AcademicSciences Pvt Ltd. This is an open access article under the CC BY license (http://creativecommons. org/licenses/by/4. 0/) DOI: http://dx.doi.org/10.22159/ajpcr.2017.v10s5.23092

\section{INTRODUCTION}

Anemia that occurs during pregnancy is a major global health problem [1]. Anemia in pregnant women can increase the risk of preterm labor, low birth weight babies, pregnancy complications such as placenta abruption, placenta previa, and giving contribution to maternal mortality [2-4]. The World Health Organization data estimates that the number of pregnant women around the world who have anemia is $41.8 \%$, and at least half of these cases are caused by iron deficiency [5]. In 2013 , the percentage of pregnant women in Indonesia with anemia was $37.1 \%[6,7]$. The government has launched a program to distribute iron supplements to pregnant women to be taken daily during pregnancy (or distributing a minimum of 90 tablets) [8]. However, Basic Health Research 2013 found that $10.9 \%$ of pregnant women did not take their iron supplements, and the number of women who took their supplements for 90 days or more was only 33.3\% [7]. This illustrates that overall compliance with taking iron supplements is low [9].

The Depok city government through the Department of Health runs a program to distribute iron supplements to pregnant women, which includes community health clinics (puskesmas). However, the Indonesian Ministry of Health (2013) data show that the number of pregnant women in the city of Depok who actually took their iron supplements for 90 days or more was only 61.5\% [7]. The problem is that distributions of the iron supplements by pharmacists in puskesmas are not accompanied by counseling due to the limited number of pharmaceutical workers and high demand for prescription services [10]. Counseling is a process of providing opportunities for patients to know about drug therapy and increase awareness of use medicine appropriately [11]. Lack of patient-related drug knowledge may increase the risk of patients not committing to their therapy [12]. Therefore, it is necessary to find the most effective method for providing information related to drug therapy to patients without adding to the pharmacists' workload.
The use of traditional health promotion media such as leaflets and pamphlets can improve maternal compliance with iron supplement consumption and improve hemoglobin levels $[12,13]$. However, the development of information technology increasingly makes short message service (SMS) a viable option for the health interventions [14]. SMS reminders are a relatively simple method that features low interference and relatively low cost [15].

The present study uses the comparative method by providing either leaflets or SMS reminders without any additional form of intervention. The purpose of this study was to obtain an overview of sociodemographic characteristics (age, education, and occupation) and clinical characteristics (parity, drug side effects, number of iron supplements, and diet) of pregnant women at two puskesmas in Depok city and to assess the effectiveness of SMS reminders compared to leaflets in complying with taking iron supplements and improving hemoglobin levels.

\section{METHODS}

This study was conducted using a pseudoexperimental method and was conducted prospectively. It used two groups of unpaired interventions with a pre-test and post-test group design. The study population comprised pregnant women who checked themselves into Sukmajaya Public Health Center and Pancoran Mas Health Center from March to May 2016. The sample size was determined from the minimum sample size table for the hypothesis test on two population proportions [16], with a significance level set at $95 \%$, a power test set at $90 \%$, a proportion of previous research compliance of $15 \%$ [12], and an expected compliance proportion of $50 \%$. This led to a minimum sample amount of 36 respondents. In anticipation of possible drop outs, the sample size was increased to 58 respondents for the leaflet group and 48 respondents for the SMS reminders group. 
Samples were taken through a consecutive sampling method. The inclusion criteria for the sample were women in their second or third trimester (gestational age 14-32 weeks), who go to puskesmas and who receive iron supplements, who have cell phones (for the SMS reminders group), who can read, and who are willing to be respondents in the study. The exclusion criteria included pregnant women who signed an informed consent form but did not come to the clinic during the study period and pregnant women who signed the informed consent form but did not complete the study.

The independent variable was a health education media intervention in the form of leaflets and SMS reminders. Leaflets were given to the respondents once at the time they were given iron supplements; SMS reminders were sent once per week for 1 month after administration of iron supplements. The dependent variables were the regimen compliance level, measured by the MMAS- 8 questionnaire and the hemoglobin level, measured by $\mathrm{HemoCue}{ }^{\circledR}$. Filling out the questionnaire and checking each participant's hemoglobin level were done twice once before and once after the intervention. Interference variables included age, education, parity, knowledge of anemia and iron supplements, drug side effects, and food sources of heme. Data analysis was carried out statistically with computer software.

\section{RESULTS}

The sociodemographic characteristics of the respondents (leaflet group and SMS reminders group) are listed in Table 1. The largest percentage of participants were aged 20-35 years, were well educated (Sekolah Lanjutan Tingkat Atas-Perguruan Tinggi) and were not working. The result of the statistical analysis between the two intervention groups showed that there were no differences regarding each variable.

The clinical characteristics of the respondents are listed in Table 2 . $71.62 \%$ of respondents have had previous births, $90.54 \%$ already knew about anemia and iron supplement tablets, 59.46\% respondents had no side effects from taking iron supplements, $74.32 \%$ of respondents took 20 iron supplements during the 1 month of the study, and $51.35 \%$ consumed food sources of heme every day. The most common side effects of the supplements were nausea/vomiting and constipation (Buang Air Besar). The results of the statistical analysis comparing the two intervention groups showed no differences between the leaflet group and the SMS reminders group for each variable. Based on the MMAS-8 scores, the health education media intervention in the form of leaflets or SMS reminders had an effect on the respondents' compliance. Fig. 1 shows the percentage change in the number of respondents based on their MMAS-8 scores before and after the intervention.
Table 1: Sociodemographic characteristics of respondents

\begin{tabular}{|c|c|c|c|}
\hline \multirow[t]{2}{*}{ Characteristics/variables } & \multicolumn{2}{|c|}{ Frequency $(n, \%)$} & \multirow[t]{2}{*}{$\mathbf{p}$} \\
\hline & $\begin{array}{l}\text { Leaflets } \\
\text { (n total=38) }\end{array}$ & $\begin{array}{l}\text { SMS } \\
\text { reminders } \\
\text { (n total=36) }\end{array}$ & \\
\hline \multicolumn{4}{|l|}{ Age (years) } \\
\hline$<20$ & $0(0)$ & $1(2.8)$ & $0.653^{\mathrm{a}}$ \\
\hline $20-35$ & $29(76.3)$ & $24(66.7)$ & \\
\hline$>35$ & $9(23.7)$ & $11(30.5)$ & \\
\hline \multicolumn{4}{|l|}{ Education } \\
\hline Elementary & $9(23.7)$ & 7 (19.4) & $0.660^{\mathrm{a}}$ \\
\hline Advanced & $29(76.3)$ & $29(80.6)$ & \\
\hline \multicolumn{4}{|l|}{ Occupation } \\
\hline Working & $2(5.3)$ & $4(11.1)$ & $0.357^{\mathrm{b}}$ \\
\hline Not working & 36 (94.7) & $32(88.9)$ & \\
\hline
\end{tabular}

aStatistical analysis result of the Mann-Whitney U-test; 'bstatistical analysis result of the Chi-squared test

Table 2: Clinical characteristics of the respondents

\begin{tabular}{|c|c|c|c|}
\hline \multirow{2}{*}{$\begin{array}{l}\text { Characteristics/ } \\
\text { variables }\end{array}$} & \multicolumn{2}{|c|}{ Frequency (n, \%) } & \multirow[t]{2}{*}{$\mathbf{p}$} \\
\hline & $\begin{array}{l}\text { Leaflets } \\
\text { (n total=38) }\end{array}$ & $\begin{array}{l}\text { SMS } \\
\text { reminders } \\
\text { (n total=36) }\end{array}$ & \\
\hline \multicolumn{4}{|l|}{ Parity } \\
\hline Nullipara & $12(31.6)$ & $9(25)$ & \multirow[t]{4}{*}{$0.097^{\mathrm{a}}$} \\
\hline Primipara & $17(44.7)$ & $10(27.8)$ & \\
\hline Multipara & $9(23.7)$ & $17(47.2)$ & \\
\hline Grande multipara & $0(0)$ & $0(0)$ & \\
\hline \multicolumn{4}{|l|}{ Knowledge } \\
\hline Knew & $32(84.2)$ & 35 (97.2) & \multirow[t]{2}{*}{$0.056^{\mathrm{b}}$} \\
\hline Did not know & $6(15.8)$ & $1(2.8)$ & \\
\hline \multicolumn{4}{|l|}{ Side effects } \\
\hline Had side effects & $16(42.1)$ & $14(38.9)$ & \multirow[t]{2}{*}{$0.778^{\mathrm{b}}$} \\
\hline $\begin{array}{l}\text { Did not have side } \\
\text { effects }\end{array}$ & $22(57.9)$ & $22(61.1)$ & \\
\hline \multicolumn{4}{|l|}{ Number of tablets } \\
\hline$<20$ tablets & $10(26.3)$ & $9(25)$ & \multirow[t]{2}{*}{$0.898^{\mathrm{a}}$} \\
\hline$>20$ tablets & 28 (73.7) & $27(75)$ & \\
\hline \multicolumn{4}{|l|}{ Heme food sources } \\
\hline Everyday & $16(4.1)$ & 22 (61.1) & \multirow[t]{2}{*}{$0.102^{b}$} \\
\hline Not everyday & $22(57.9)$ & $14(38.9)$ & \\
\hline
\end{tabular}

aStatistical analysis result of the Mann-Whitney U-test; bstatistical analysis result of the Chi-squared test

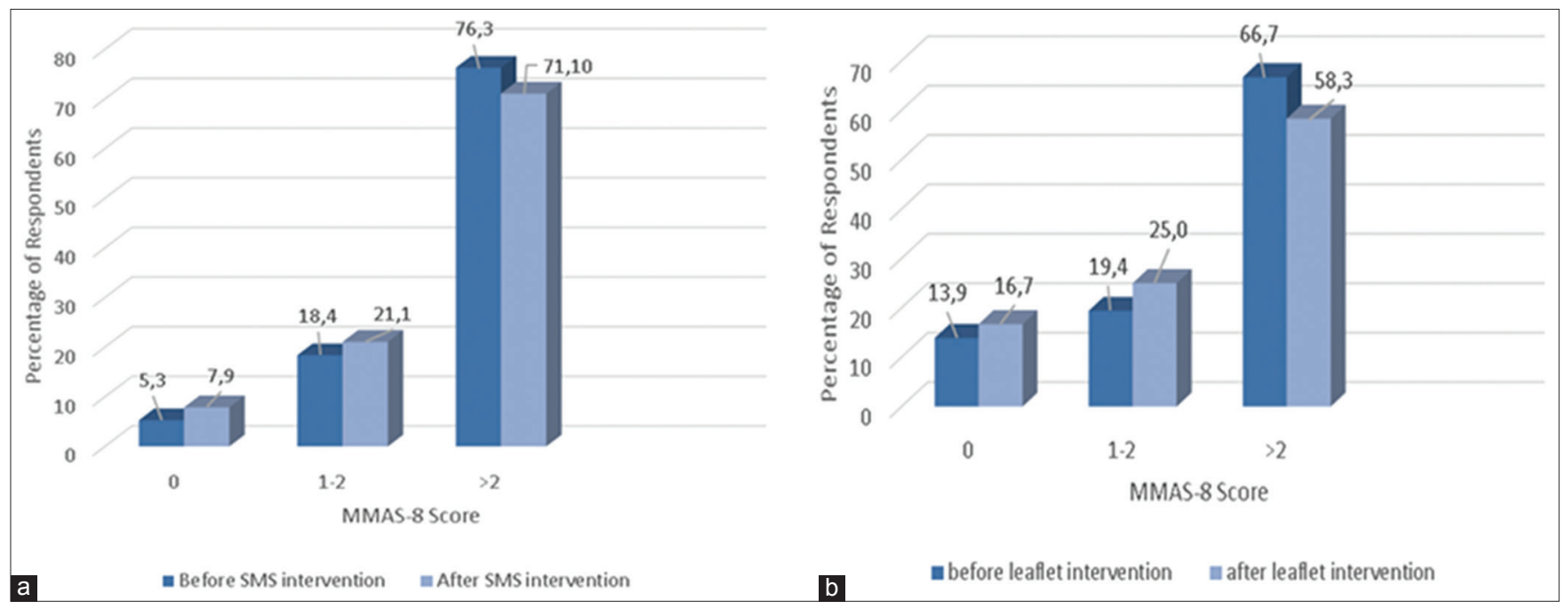

Fig. 1: ( $a$ and b) Percentage of leaflet and short message service reminder respondents based on MMAS-8 score before and after intervention 
Examination of hemoglobin levels was used to determine the participants' anemia status. Fig. 2 shows the percentage change in the number of respondents based on their hemoglobin levels before and after the intervention. Statistical tests were performed to determine the differences in compliance levels and hemoglobin levels (before and after the intervention) between the leaflet group and the SMS reminders group. The full results are shown in Tables 3 and 4.

\section{DISCUSSION}

In the MMAS-8, a total score of 0 indicates that the patient complied with his or her therapy, 1 and 2 indicate medium or moderate compliance, and $>2$ indicates that the patient did not comply with his or her therapy. The lower the total MMAS-8 score, the higher the patient's compliance with his or her therapy.

Fig. 1 shows the percentage change in respondents' MMAS-8 scores before and after the intervention. The percentage of respondents with MMAS- 8 scores $>2$ decreased, whereas the percentage of respondents with MMAS- 8 scores of 0,1 , and 2 increased. This indicates that after the intervention, there was a decrease in the percentage of respondents in the non-compliance category and an increase in the percentage of respondents in the medium and obedient compliance categories.

Classification of maternal anemia status based on hemoglobin level was categorized as no anemia if hemoglobin was $\geq 11 \mathrm{~g} / \mathrm{dl}$, mild anemia if hemoglobin was $10.9-10.0 \mathrm{~g} / \mathrm{dl}$, moderate anemia if hemoglobin was 9.9-7.0 g/dl, and severe anemia if hemoglobin was < $7.0 \mathrm{~g} / \mathrm{dl}$ [17]. Fig. 2 shows the percentage change in hemoglobin levels before and after the intervention. The percentage of respondents with hemoglobin $\geq 11 \mathrm{~g} / \mathrm{dl}$ increased by $2.63 \%$ in the leaflet group and $5.56 \%$ in the SMS reminders group. This shows that after giving the intervention, there was an increase in the percentage of respondents categorized as no anemia.

The results of the statistical test SPSS show a significant change in the level of compliance of respondents, but there was no significant change in the hemoglobin levels of respondents before and after the leaflets.
A total of 19 respondents out of the 38 respondents in the leaflet group increased their average hemoglobin levels by $0.6 \mathrm{~g} / \mathrm{dl}$. The statistical results of the SMS reminders group showed that there was no significant change in compliance level or hemoglobin level before or after the intervention. A total of 17 out of 36 respondents in the SMS reminders group experienced an increase of $1.1 \mathrm{~g} / \mathrm{dl}$ in their average hemoglobin level. The full results are listed in Table 3. Table 4 shows no significant differences in the results of the statistical analysis between compliance levels and hemoglobin levels in the leaflet and SMS reminders groups.

Some differences between the results of the present study and previous studies are significantly improved compliance and hemoglobin levels after leaflet and SMS reminders that were due to differences in the sociodemographic and clinical characteristics of the respondents, differences in procedures/methods, duration, and sample size. In this study, the intervention was only leaflets or SMS reminders without any additional form of intervention. Information on the material in the leaflets was given directly by the pharmacist, but only briefly and not intensively, so the respondents were less able to absorb the information well.

This study had several limitations. One factor that may have influenced the results is the clinical characteristics of the respondents; $73.68 \%$ of the respondents in the leaflet group and $66.67 \%$ of the respondents in the SMS reminders group were in the second trimester of their pregnancy, during which time hemoglobin levels naturally decrease by about $0.5 \mathrm{~g} / \mathrm{dl}$ due to hemodilution [17]. Further, $42.1 \%$ of the leaflet group and $61.1 \%$ of the SMS reminders group consumed food sources of heme every day, but the researchers did not get information about the amount of the heme source being consumed. A study by Vernissa concluded that pregnant women who ate heme sources daily increased their hemoglobin levels by 2.31 times compared with those who did not eat the heme source every day [13].

\section{CONCLUSION}

The majority of the respondents in this study were pregnant women with a history of one-time labor, knowledge of anemia and iron supplements did

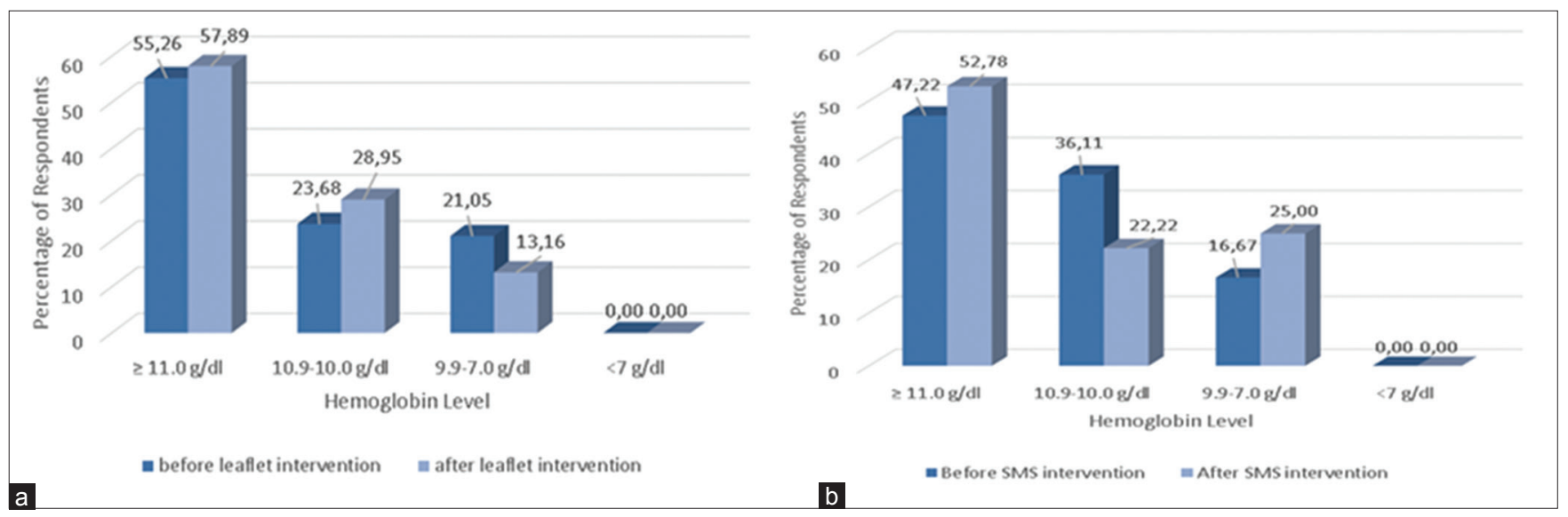

Fig. 2: (a and b) Percentage of leaflet and short message service (SMS) reminder respondents based on hemoglobin levels before and after leaflet and SMS reminders delivery

Table 3: Average MMAS-8 score \pm SD and hemoglobin levels before and after leaflet and SMS reminders delivery

\begin{tabular}{|c|c|c|c|c|c|c|}
\hline \multirow{2}{*}{ Variables } & \multicolumn{2}{|l|}{ Leaflet } & \multirow[t]{2}{*}{$\mathbf{p}$} & \multicolumn{2}{|c|}{ SMS reminder } & \multirow[t]{2}{*}{$\mathbf{p}$} \\
\hline & Before & After & & Before & After & \\
\hline MMAS-8 score & $4.26 \pm 2.36$ & $3.45 \pm 1.94$ & $0.018^{\mathrm{a}}$ & $3.50 \pm 2.36$ & $2.94 \pm 2.11$ & $0.180^{\mathrm{b}}$ \\
\hline Hemoglobin levels (g/dl) & $11.2 \pm 1.36$ & $11.1 \pm 1.22$ & $0.553^{\mathrm{a}}$ & $11.0 \pm 1.36$ & $10.9 \pm 1.19$ & $0.798^{\mathrm{a}}$ \\
\hline
\end{tabular}

a: Paired $t$ test, ${ }^{\text {b: }}$ Wilcoxon, SMS: Short messaging service, SD: Standard deviation 
Table 4: Average change in MMAS-8 scores and hemoglobin levels in leaflet group and SMS reminders group

\begin{tabular}{llll}
\hline Variable & \multicolumn{2}{l}{ Average change } & p \\
\cline { 2 - 3 } & Leaflet & SMS reminder & \\
\hline MMAS-8 score & 0.81 & 0.56 & $0.576^{\mathrm{a}}$ \\
Hemoglobin level $(\mathrm{g} / \mathrm{dl})$ & -0.05 & -0.08 & $0.929^{\mathrm{b}}$ \\
\hline
\end{tabular}

aStatistical analysis result of the Mann-Whitney U-test; 'bstatistical analysis result of the Chi-squared test. SMS: Short messaging service

not experience any iron supplement side effects, and consumed $>20$ iron supplements during their pregnancies as well as heme food sources daily. Distributing leaflets can significantly increase respondent compliance $(p=0.018)$ but not significantly increase hemoglobin levels $(p=0.553)$. The SMS reminders did not significantly increase respondent compliance or hemoglobin levels ( $\mathrm{p}=0.180$ and $\mathrm{p}=0.798$, respectively). There was no significant difference between distributing leaflets and sending SMS reminders in changing compliance levels or hemoglobin levels $(\mathrm{p}=0.576$ and $p=0.929$, respectively). Respondents with a gestational age past the second trimester were an inclusion criterion to minimize the effect of hemodilution that occurred in the respondents. In the future, it would be useful to do research lasting more than 1 month to determine the impact of leaflets and SMS reminders on the levels of compliance and hemoglobin in pregnant women throughout their pregnancy. Finally, the future research should measure the amount and source of heme consumed to identify the influence of heme source on hemoglobin levels.

\section{REFERENCES}

1. World Health Organization. Iron Deficiency Anaemia: Assessment, Prevention and Control: A Guide for Programme Managers. Geneva: World Health Organization; 2001.

2. Allen LH. Anemia and iron deficiency: Effects on pregnancy outcome. Am J Clin Nutr 2000;71 5 Suppl:1280S-4.

3. Lee AI, Okam MM. Anemia in pregnancy. Hematol Oncol Clin North Am 2011;25(2):241-59, vii.

4. Levy A, Fraser D, Katz M, Mazor M, Sheiner E. Maternal anemia during pregnancy is an independent risk factor for low birthweight and preterm delivery. Eur J Obstet Gynecol Reprod Biol 2005;122(2):182-6.
5. World Health Organization. Worldwide Prevalence of Anaemia 19932005: WHO Global Database on Anaemia. Geneva: World Health Organization; 2008.

6. Wijaya-Erhardt M, Muslimatun S, Erhardt JG. Fermented soyabean and vitamin C-rich fruit: A possibility to circumvent the further decrease of iron status among iron-deficient pregnant women in Indonesia. Public Health Nutr 2011;14(12):2185-96.

7. Kementerian Kesehatan Republik Indonesia. Riset Kesehatan Dasar Tahun 2013. Jakarta: Kementerian Kesehatan Republik Indonesia; 2013.

8. Minister of Health Republic of Indonesia. Regulation of Minister of Health of the Republic of Indonesia, No. 88, 2014 about Standard of Tablet to Increase of Haemoglobin in Women Childbearing Age and Pregnant Women; 2014.

9. Wibowo N, Irwinda R. The effect of multi-micronutrient and protein supplementation on iron and micronutrients status in pregnant women. Med J Indones 2015;24(3):168-75.

10. Supardi S. Kebijakan Penempatan Apoteker Sebagai Pengelola Obat di Puskesmas (Laporan Penelitian). Jakarta: Pusat Teknologi Intervensi Kesehatan Masyarakat; 2011.

11. Departemen Kesehatan Republik Indonesia. Pedoman Konseling Pelayanan Kefarmasian di Sarana Kesehatan. Jakarta: Direktorat Bina Farmasi Komunitas dan Klinik Direktorat Jenderal Bina Kefarmasian dan Alat Kesehatan Departemen Kesehatan RI; 2007.

12. Adawiyani R. The effect of giving anemia booklet towards the pregnant Women's knowledge, adherence to consume TTD, and haemoglobin. J Ilmiah Mahasiswa Univ Surabaya 2013;2(2):1-20.

13. Vernissa V. Efektivitas Leaflet Terhadap Kepatuhan Minum Tablet Tambah Darah dan Kadar Hemoglobin Ibu Hamil Dengan Anemia di Puskesmas Cileungsi Kabupaten Bogor. Thesis. Depok: Universitas Indonesia; 2012.

14. Clauson KA, Elrod S, Fox BI, Hajar Z, Dzenowagis JH. Opportunities for pharmacists in mobile health. Am J Health Syst Pharm 2013;70(15):1348-52.

15. Cocosila M, Archer N. A framework for mobile healthcare answers to chronically ill outpatient non-adherence. Inform Prim Care 2005;13(2):145-52.

16. Lwanga SK, Lemeshow S. Sample Size Determination in Health Studies: A Practical Manual. Geneva: World Health Organization; 1991.

17. World Health Organization. Haemoglobin Concentrations for the Diagnosis of Anaemia and Assessment of Severity. Geneva: World Health Organization; 2011. 